\title{
The State Financial Recovery on Criminal Acts of Corruption through Approach to Criminal Claim
}

\author{
Grahita Fidianto*), Umar Ma'ruf*) and Aryani Witasari***) \\ *) Prosecutor, E-mail: grahitafidi@gmail.com \\ **) Faculty of Law, Universitas Islam Sultan Agung (UNISSULA) Semarang \\ $\left.{ }^{* * *}\right)$ Faculty of Law, Universitas Islam Sultan Agung (UNISSULA) Semarang
}

\begin{abstract}
.
The purpose of this study is to find out and analyze the practice of imposing additional criminal charges in the form of payment of compensation, and how the concept of recovering state financial losses based on asset confiscation in the Corruption Crime Act. The method used in writing this law uses a normative juridical approach. The results of this study are that the practice of recovering state financial losses through additional criminal penalties in the form of payment of compensation is still limited to articles containing elements of state financial losses, while the level of success depends on the level of awareness or willingness of the convict to pay. The imposition of additional crimes in the form of confiscation of the convict's assets is not limited to corruption offenses with elements of state financial losses, and the success rate depends on the ability of the investigator to collect the convict's assets related to corruption, as well as the ability of the public prosecutor to prove the corruptionrelated property during the trial.
\end{abstract}

Keywords: Corruption; Financial; Money; Recovery; Replacement; State.

\section{Introduction}

Corruption is one of the serious problems facing the Indonesian people. Corruption is clearly very dangerous for the nation because its impact is not only detrimental to state finances but also hinders the state or government in the welfare of society. The community is also affected by the actions of the perpetrators who only benefit themselves, their families, and their cronies. ${ }^{1}$

Regarding the disclosure of criminal acts of corruption, Yudi Kristiana stated that law enforcers have revealed many corruption cases, however, from the corruption cases revealed, law enforcers have only succeeded in imprisoning people, but have not succeeded in returning assets. ${ }^{2} \mathrm{~A}$ similar opinion was also expressed by Muhammad Yusuf based on the experience of Indonesia and other countries showing that uncovering criminal acts, finding the perpetrators and placing the perpetrators of criminal acts in prison (follow the suspect) is not effective enough to reduce the crime rate if it is not accompanied by efforts to confiscate and confiscate the proceeds and instruments of criminal acts, in this

${ }^{1}$ Joko Hermawan Sulistyo \& Jawade Hafidz, Application in Lieu of Money Penalty to Corruption Actors Based on Act No. 31 of 1999 jo. Act No. 20 of 2001 on Combating Crime of Corruption, Artikel dalam Jurnal Daulat Hukum Vol. 1 No. 4 (2018) url : http://jurnal.unissula.ac.id/index.php/RH/article/view/4142/2892\#, accessed on 20 September 2021 at 16.00 WIB

2Yudi Kristiana, 2016, Pemberantasan Tindak Pidana Korupsi Perspektif Hukum Progresif, Thafa Media, Yogyakarta, p. 23 
case allowing the perpetrators of criminal acts to remain in control of the proceeds and instruments of criminal acts providing opportunities for criminals or other people who are related to the perpetrators of criminal acts to enjoy the proceeds of criminal acts and reuse the instruments of criminal acts or even develop criminal acts that have been committed. ${ }^{3}$

In line with the opinion as stated above, the reality of handling corruption crimes today is that most law enforcement officers are still oriented to corporal punishment imposed on corruptors, while the focus on recovering state financial losses has not run optimally.

According to Romli Atmasasmita, the recovery of state financial losses has not been maximized because the current legal instruments in Indonesia have not been able to optimally regulate and accommodate activities in the context of recovering assets resulting from corruption and crimes in finance and banking in general. $^{4}$

The Corruption Crime Act has actually accommodated the provisions regarding recovery of state financial losses, namely by applying additional sanctions to corruptors, namely additional penalties in the form of payment of replacement money as regulated in Article 18 of the Corruption Crime Act. However, in practice, when dealing with the law, the corruptors do not necessarily voluntarily hand over the property obtained from the crime of corruption to the state.

Another problem faced by law enforcement officials in recovering state financial losses is when corruptors have transferred assets resulting from crimes abroad, or under certain conditions the perpetrators of corruption have died before there is a court decision that has permanent legal force, so that the obstacles the provisions of the legislation in force at this time, resulting in state financial losses that cannot be recovered. Starting from this background, it is necessary to have special thoughts to overcome the problem of recovering state financial losses in criminal acts of corruption.

Based on the background as stated by the author above, the purpose of this study is to find out and analyze the practice of imposing additional criminal charges in the form of payment of compensation, and how the concept of recovering state financial losses based on asset confiscation in the Corruption Act.

\section{Research Methods}

The method used in writing this law uses a normative approach, while the research specifications used are descriptive - analytical. The type of data used is secondary data, while the secondary data in this study comes from primary legal materials, secondary legal materials, and tertiary legal materials. The data

\footnotetext{
${ }^{3}$ Muhammad Yusuf, 2012, Merampas Aset Koruptor Solusi Pemberantasan Korupsi di Indonesia, Penerbit Buku Kompas, Jakarta, p. 6

${ }^{4}$ Marfuatul Latifah, Urgensi Pembentukan Undang-Undang Perampasan Aset Hasil Tindak Pidana di Indonesia, Jurnal Negara Hukum 6, 2015, hlm. 19 url : https://jurnal.dpr.go.id/index.php/hukum/article/view/244 accessed on 20 September 2021 at 16.00 WIB
} 
collection method used is literature study and document study, while the data analysis method uses qualitative analysis.

\section{Results and Discussion}

\subsection{The practice of imposing additional penalties in the form of payment of replacement money}

Eradication of criminal acts of corruption is not only done by ensnaring the perpetrators to be sentenced to imprisonment. The imposition of witnesses needs to be considered properly, considering that in the provisions of the Corruption Crime Act there is a classification of offenses that mentions the element of "state financial losses", namely those contained in the provisions of Articles 2 and 3.

According to the provisions of Article 1 number 22 of Act No. 1 of 2004 concerning the State Treasury, state/regional financial losses are shortages of money, securities, and goods, which are real and definite in amount as a result of unlawful acts, either intentionally or negligently. As a result of the loss of state finances is a real result of the corrupt actions of the perpetrators of corruption, so it is fitting that the corruptor is absolutely responsible for returning the results of his corruption to the state.

Compensation money in the context of returning state financial losses in corruption is a sum of money that must be paid by a defendant who is proven legally and convincingly according to the law based on a court decision, because his act of committing a criminal act of corruption caused state financial losses. ${ }^{5}$

The application of criminal sanctions to corruptors in the context of criminal acts of corruption that cause state financial losses needs attention, of course it is not only corporate crimes that are applied, considering that there are consequences, namely state financial losses, so that additional criminal sanctions need to be imposed on corruptors. The imposition of additional criminal witnesses is intended to provide witnesses who are far more in line with the needs for treatment of the perpetrator, recovery from the consequences of the crime caused and at the same time providing protection to the public. ${ }^{6}$ Additional criminal status in criminal law in Indonesia is regulated in the provisions of Article 10 of the Criminal Code, which states that the criminal offense consists of a principal crime and an additional crime.

The additional punishment imposed on the perpetrators of corruption as referred to in Act No. 31 of 1999 as amended by Act No. 20 of 2001 concerning the Eradication of Criminal Acts of Corruption is an additional penalty of replacement money. Additional criminal sanctions in the form of payment of replacement money are important, because one of the goals to be achieved in eradicating corruption is the return of state financial losses. ${ }^{7}$. Compensation money is declared as an additional crime, because the substitute money follows the main crime,

\footnotetext{
5 Husin Wattimena, 2017, Penerapan Ancaman Sanksi Pidana Tambahan Bagi Pengembalian Kerugian Keuangan Negara Dalam Tindak Pidana Korupsi, First Printing, Dee-publish, Yogyakarta, p. 7

${ }^{6}$ Yudi Kristiana, Op. Cit, p. 59

${ }^{7}$ Ibid, p. 60.
} 
because by being proven to have committed an act that is detrimental to the state, all assets obtained from a criminal act of corruption are withdrawn as replacement money with the aim that what has been enjoyed is returned to the state as the subject who was harmed ${ }^{8}$.

According to Andi Hamzah, the purpose of sentencing is reform, restraint, retribution, and deterrence ${ }^{9}$.The purpose of sentencing in the context of reform as stated above is interpreted as repairing or recovering the convict to return to being a better human being. In a broader perspective, the imposition of additional criminal charges in the form of replacement money can be seen as an effort to reform or restore state finances to their original state before the occurrence of corruption.

Additional punishment in the form of payment of replacement money is regulated in Article 18 Paragraph (1) letter b of the Corruption Crime Act, which states that the payment of replacement money is as much as the amount equal to the property obtained from the crime of corruption. The term replacement money itself has been mentioned since the previous statutory provisions, namely in Act No. 3 of 1971 concerning the Eradication of Criminal Acts of Corruption.

The practice of applying additional criminal payments in exchange for money in the field is mostly applied to corrupt actors who violate Article 2 or Article 3 only ${ }^{10}$. Although the provisions of Article 17 of the Corruption Crime Act do not limit the application of compensation to only Article 2 and Article 3, Articles 5 to 14 do not mention the element of state financial loss in the formulation of the offense.

In relation to the additional criminal payment of substitute money, the Supreme Court has issued Supreme Court Regulation No. 5 of 2014 concerning the additional penalty of substitute money in Corruption Crimes. In the provisions of Article 1 it states "In determining the amount of payment of compensation in a criminal act of corruption, the amount is equal to the amount of property obtained from a criminal act of corruption and not merely a number of state financial losses caused". Furthermore, in the provisions of Article 3 it is stated that "An additional penalty of replacement money can be imposed on all corruption crimes as regulated in Chapter II of Act No. 31 of 1999 as amended by Act No. 20 of 2001 concerning Eradication of Corruption Crimes with due regard to the provisions of Article 1".

From the perspective of legislation, state losses have caused problems and have a serious impact both in the economy and in solving problems in the field of state finances ${ }^{11}$. According to Yudi Kristiana, the consequences of corruption are not only state losses, because the source of the money comes from state finances or the state economy or what is enjoyed is state money, but the impact has the

\footnotetext{
${ }^{8}$ Kristwan Genova Damanik, Antara Uang Pengganti dan Kerugian Negara Dalam Tindak Pidana Korupsi, Masalah - Masalah Hukum, Vol. 45 No. 1 (2016), url : https://ejournal.undip.ac.id/index.php/mmh/article/view/13665/10416, accessed on October 14, 2021 at 12.30 WIB

${ }^{9}$ Andi Hamzah, 2008, Asas - Asas Hukum Pidana, Rineka Cipta, Jakarta, p. 28 - 29.

10Ibid, p. 62

11Widyo Pramono, 2016, Pemberantasan Korupsi dan Pidana Lainnya Sebuah Perspektif Jaksa, Penerbit Buku Kompas, Jakarta, p. 283
} 
potential to cause losses that could be in larger amounts, for example corruption in the form of counterfeiting, manipulation either by means of technology on taxation data, banking has the potential to cause state revenues to be smaller than it should be, as well as manipulation in the mining or energy sector which has the potential to result in large losses ${ }^{12}$.

Thinking about the impact of corruption as stated above is a serious problem that is being faced by this nation, so it is appropriate that additional punishment in the form of payment of replacement money should also be applied outside of corruption offenses other than Article 2 and Article 3, as additional sanctions for corruptors. Considering that in every criminal act that occurs, a proportional criminal punishment is needed, which ensures that the criminal punishment must at least be proportional to the losses caused by the crime, the appropriate sanctions must be in accordance with the severity of the act and the losses incurred by the violator. ${ }^{13}$

Based on the applicable laws and regulations, the application of the criminal payment of replacement money is certainly a challenge for law enforcement officials, considering that the replacement money is imposed based on the proceeds of property obtained from corruption, because it does not rule out the possibility of corruptors transferring these assets to other people.

R. Wiyono stated that property obtained from a criminal act of corruption as referred to in Article 18 Paragraph (1) letter b of the UUPTPK should not only be interpreted as property obtained from the proceeds of a criminal act of corruption which was "still controlled" by the convict at the time the court rendered its decision but it is interpreted as including property obtained from the proceeds of a criminal act of corruption, which at the time the court renders its decision, the property has been transferred by the defendant to another person. ${ }^{14}$

Corruption has its own characteristics compared to other types of crime, one of the characteristics of corruption is that corruption is classified as a crime which is correlated with money and power. ${ }^{15}$. Perpetrators of corruption who usually have power tend to be able to control various things, so that it is correlated with the increasingly complex handling of criminal acts of corruption, including in terms of hiding assets resulting from corruption. The increasingly complex modes of corruption, of course, it will be difficult to disclose if law enforcement officers are only fixated on the approach of the law on corruption, because corruptors must have prepared scenarios to hide or disguise the results of their corruption, so that a money laundering approach is needed in handling corruption.

Correlation of compensation payments borne by convicts of corruption depends on the individual conditions of the convict, conceptually it can be concluded that the payment of compensation depends on the level of awareness

\footnotetext{
${ }^{12}$ Yudi Kristiana, Op. Cit, p. 66

${ }^{13}$ T.J Gunawan, 2015, Konsep Pemidanaan Bebasis Nilai Kerugian Ekonomi, Menuju Sistem Hukum Pidana yang Berkeadilan, Berkepastian, Memberi Daya Deteren dan Mengikuti Perkembangan Ekonomi, First Printing, Genta Press, Yogyakarta, p. 97.

${ }^{14} \mathrm{R}$. Wiyono, 2012, Pembahasan Undang - Undang Tindak Pidana Korupsi, Second Edition, Third Printing, Sinar Graphic, Jakarta, p. 143

${ }^{15}$ Yudi Kristiana, 2017, Teknik Penyidikan dan Pemberkasan Tindak Pidana Korupsi, Thafa Media, Yogyakarta, p. 1
} 
and willingness of the convict himself. In practice in the field, it is not uncommon for convicts to prefer to serve imprisonment as a substitute for paying replacement money, on the pretext that they no longer have the property to pay the replacement money. ${ }^{16}$

The convict who does not pay the replacement money after 1 (one) month of the court's decision has permanent legal force, the prosecutor will confiscate the convict's property to be auctioned, and the proceeds are used to cover the replacement money. ${ }^{17}$. Observing these provisions, it is necessary to make clear boundaries regarding the property belonging to the convict that can be confiscated by the prosecutor. In addition, the time limit given for 1 (one) month is of course a short time, so it needs to be reviewed through legislation policy. ${ }^{18}$

According to R. Wiyono's opinion, regarding the assets of the convict confiscated by the prosecutor as referred to in Article 18 Paragraph (2) of the UUPTPK, namely property belonging to the convict which is not property resulting from a criminal act of corruption and/or property belonging to the convict which is not used to commit the corruption crime ${ }^{19}$.

The confiscation of the convict's property within the scope of the provisions of Article 18 Paragraph (2) of the PTPK Law is certainly not easy to implement. The inventory of the convict's property is certainly important as a further step for the prosecutor in conducting the confiscation, regarding which objects will be confiscated for auction. Considering that the property to be confiscated is not property that is not related to the criminal act of corruption committed.

Departing from the issue of payment of replacement money as stated above, the payment of replacement money as an implementation at the execution stage of corruption cases is certainly related to the process of handling cases starting from the investigation stage. Bearing in mind that based on the provisions of Article 28 of the UUPTPK, at the stage of investigation, a suspect is required to provide information regarding his property and his family. Therefore, investigators must be maximal, not only to find the suspect's guilt, but also to track down all of the suspect's property, both directly related to corruption and property not related to corruption.

In line with what the author stated above, Rudi Pardede said that in the context of recovering state financial losses, one of the factors that affect the return of state financial losses is the inability of investigators to track the whereabouts of property resulting from corruption. ${ }^{20}$

\footnotetext{
${ }^{16}$ Hery Purwanto \& Siti Ummu Adillah, The Recovery of Assets Results of Corruption Throught Additional Criminal Payment of Replacement Money, Artikel dalam Law Development Journal (LDJ) Vol. 3 No. 2 (2021) url : http://jurnal.unissula.ac.id/index.php/ldj/article/view/15994/5722, p. 127

${ }^{17}$ Article 18 Paragraph (2) UUTPK

${ }^{18}$ Hery Purwanto \& Siti Ummu Adillah, The Recovery of Assets Results of Corruption Throught Additional Criminal Payment of Replacement Money, Artikel dalam Law Development Journal (LDJ) Vol. 3 No. 2 (2021) url : http://jurnal.unissula.ac.id/index.php/ldj/article/view/15994/5722 accessed on October 14, 2021 at 12.30 WIB

${ }^{19} \mathrm{R}$. Wiyono, Op. Cit, p. 146

${ }^{20}$ Rudi Pardede, 2017, Proses Pengembalian Kerugian Negara Akibat Korupsi, Second Printing, Revised Edition, Genta Publishing, Yogyakarta, p. 125
} 


\subsection{The concept of recovering state financial losses based on asset confiscation according to the Corruption Crime Act}

The provisions in the law on eradicating corruption in force currently have substantially regulated the seizure of assets belonging to corruption convicts. The formulation of the confiscation of assets convicts of criminal acts of corruption is classified as an additional crime imposed on the convict, as stated in Article 18 Paragraph (1) letter a UUPTPK, namely: "In addition to the additional crimes as referred to in the Criminal Code, in addition to the seizure of tangible or intangible movable goods or immovable goods used for or obtained from criminal acts of corruption, including companies owned by the convict where the crime of corruption was committed, as well as from the goods that replace the goods.

Assets are objects of economic value, both movable or immovable objects, tangible or intangible objects, and property rights (absolute and relative). ${ }^{21}$. In the provisions of UNCAC 2003, wealth is every type of asset, whether bodily or not, movable or immovable, tangible or intangible, and documents or legal instruments that prove rights to or interests in these assets. ${ }^{22}$.

Guidelines on asset recovery from the Attorney General's Office, defines assets as all objects, both material and immaterial, movable or immovable, tangible or intangible, and documents or legal instruments that have economic value. ${ }^{23}$. The 2015 Criminal Acts of Asset Confiscation Bill provides a definition of assets, namely all movable or immovable objects, both tangible and intangible and have economic value. ${ }^{24}$

The formulation of "tangible or intangible movable goods or immovable goods" as stated in the provisions of Article 18 Paragraph (1) letter a of the PTPK Law in terminology can be interpreted as assets as previously stated. The author is of the opinion that the formulation of Article 18 Paragraph (1) letter a of the UUPTPK should be clarified again by adding an editorial with economic value. The consideration is that Article 18 Paragraph (1) letter a UUPTPK is an additional crime imposed on corruptors, so that it certainly has a definite purpose, namely the confiscation of assets used for or obtained from criminal acts of corruption which will later be confiscated for the state by way of auction. so it should have economic value.

Observing the terminology used by legislators, especially in the provisions of Article 18 of the PTPK Law, it can be found that there is the use of the term "confiscation" of the convict's property as stated in Article 18 Paragraph (1) letter a, while the term "confiscation" of the convict's property is mentioned in Article 18 Paragraph (2) UUPTPK. In principle, the provisions of Article 18 Paragraph (1)

\footnotetext{
${ }^{21}$ Agustinus Herimulyanto, 2019, Sita Berbasis Nilai Pengembalian Aset Tindak Pidana Korupsi, Genta Publishing, Yogyakarta, p. 15

${ }^{22}$ Lilik Mulyadi, 2020, Model Ideal Pengembalian Aset Pelaku Tindak Pidana Korupsi, Kencana, Jakarta, p. 128

${ }^{23}$ Article 1 Number 1 Regulation of the Attorney General of the Republic of Indonesia Number: PER-013/A/JA/06/2014 dated 13 June 2014 concerning Asset Recovery.

${ }^{24}$ Lilik Mulyadi, Op. cit
} 
letter a are intended for assets related to criminal acts of corruption, while the provisions of Article 18 Paragraph (2) are intended for assets not related to criminal acts of corruption. According to UNCAC 2003, forfeiture is part of confiscation. ${ }^{25}$

The confiscation of the proceeds of a criminal act of corruption is highly dependent on the ability of the Public Prosecutor to prove the guilt of the defendant before the trial as well as to prove that the crime resulted from the criminal act that he was accused of, such a concept is referred to as seizure based assets forfeiture which means the confiscation of an asset resulting from a criminal act of corruption is very dependent on the success of the investigation and prosecution of the criminal case ${ }^{26}$.

The confiscation of the convict's property in the context of Article 18 Paragraph (1) letter a of the PTPK Law is technically related to the provisions of Article 39 of the Criminal Procedure Code. The confiscation of the convict's property begins at the investigation stage by identifying assets related to corruption. Up to this stage, investigators have taken concrete steps to carry out confiscation procedures for assets that have been identified as related to corruption. Of course, the search for these assets is not easy, the mode of asset transfer is common in Indonesia and is known to law enforcement, it's just that the speed of disclosure of cases has been going on lately compared to the use of assets resulting from corruption in economic activities so that when they are confiscated, these assets are mixed with other assets. ${ }^{27}$

All assets that have been confiscated by the investigator will later be proven by the Public Prosecutor in the trial as assets related to corruption. However, on the other hand, according to the provisions of Article 38 B Paragraph (1) of the PTPK Law, it is stated that the defendant is also given the opportunity to prove otherwise related to his property which is charged with corruption. If the defendant cannot prove otherwise, his property will be confiscated for the state. ${ }^{28}$

\section{Clossing}

Recovery of state financial losses according to the concept of the law on criminal acts of corruption can be pursued through the imposition of additional penalties, namely in the form of payment of replacement money, as well as the confiscation of the convict's assets related to corruption. The application of compensation payments is often applied to offenses containing elements of state financial losses, namely Article 2 and Article 3 of the Corruption Eradication Act, while the success rate of recovering state financial losses in the context of paying compensation is highly dependent on the level of awareness of the convict to voluntarily hand over the replacement money to the prosecutor as the executor.

\footnotetext{
${ }^{25}$ Agustinus Herimulyanto, Op. Cit, p. 35

${ }^{26}$ Muhammad Yusuf, Op. Cit, p. 162

${ }^{27}$ Ade Mahmud, Urgensi Penegakan Hukum Progresif Untuk Mengembalikan Kerugian Negara Dalam Tindak Pidana Korupsi, Masalah - Masalah Hukum, Vol. 49 No. 3 (2020), url : https://ejournal.undip.ac.id/index.php/mmh/article/view/29590/17729, accessed on October 14, 2021 at 12.30 WIB

${ }^{28}$ Article 38 B Paragraph (2) PTPK Law
} 
The imposition of additional penalties in the form of confiscation of the convict's assets is not limited to articles that contain elements of state financial losses only.

\section{References}

\section{Journals}

[1] Genova Kristwan Damanik, Antara Uang Pengganti dan Kerugian Negara Dalam Tindak Pidana Korupsi, Masalah - Masalah Hukum, Vol. 45 No. 1 (2016), url https://ejournal.undip.ac.id/index.php/mmh/article/view/13665/10416, accessed on 14 October 2021 at 12.30 WIB

[2] Latifah Marfuatul, Urgensi Pembentukan Undang-Undang Perampasan Aset Hasil Tindak Pidana di Indonesia, Jurnal Negara Hukum 6, 2015 url : https://jurnal.dpr.go.id/index.php/hukum/article/view/244 accessed on 20 September 2021 at 16.00 WIB

[3] Mahmud Ade, Urgensi Penegakan Hukum Progresif Untuk Mengembalikan Kerugian Negara Dalam Tindak Pidana Korupsi, Masalah - Masalah Hukum, Vol. 49 No. 3 (2020), url : https://ejournal.undip.ac.id/index.php/mmh/article/view/29590/17729 accessed on 14 October 2021 at 12.30 WIB

[4] Purwanto Hery \& Siti Ummu Adillah, The Recovery of Assets Results of Corruption Throught Additional Criminal Payment of Replacement Money, Artikel dalam Law Development Journal (LDJ) Vol. 3 No. 2 (2021) url : http://jurnal.unissula.ac.id/index.php/ldj/article/view/15994/5722 accessed on 14 October 2021 at 12.30 WIB

[5] Sulistyo Joko Hermawan \& Jawade Hafidz, Application in Lieu of Money Penalty to Corruption Actors Based on Act No. 31 of 1999 jo. Act No. 20 of 2001 on Combating Crime of Corruption, Artikel dalam Jurnal Daulat Hukum Vol. 1 No. 4 (2018) url : http://jurnal.unissula.ac.id/index.php/RH/article/view/4142/2892\# accessed on 20 September 2021 at 16.00 WIB

\section{Books}

[1] Agustinus Herimulyanto, 2019, Sita Berbasis Nilai Pengembalian Aset Tindak Pidana Korupsi, Yogyakarta, Genta Publishing,

[2] Gunawan T.J, 2015, Konsep Pemidanaan Bebasis Nilai Kerugian Ekonomi, Menuju Sistem Hukum Pidana yang Berkeadilan, Berkepastian, Memberi Daya Deteren dan Mengikuti Perkembangan Ekonomi, First Printing, Yogyakarta, Genta Press,

[3] Hamzah Andi, 2008, Asas - Asas Hukum Pidana, Jakarta, Rineka Cipta.

[4] Kristiana Yudi, 2016, Pemberantasan Tindak Pidana Korupsi Perspektif Hukum Progresif, Yogyakarta, Thafa Media.

[5] Kristiana Yudi, 2017, Teknik Penyidikan dan Pemberkasan Tindak Pidana Korupsi, Yogyakarta, Thafa Media.

[6] Mulyadi Lilik, 2020, Model Ideal Pengembalian Aset Pelaku Tindak Pidana Korupsi, Jakarta, Kencana. 
[7] Pardede Rudi, 2017, Proses Pengembalian Kerugian Negara Akibat Korupsi, Cetakan Kedua, Edisi Revisi, Yogyakarta, Genta Publishing,

[8] Pramono Widyo, 2016, Pemberantasan Korupsi dan Pidana Lainnya Sebuah Perspektif Jaksa, Jakarta, Penerbit Buku Kompas.

[9] Wattimena Husin, 2017, Penerapan Ancaman Sanksi Pidana Tambahan Bagi Pengembalian Kerugian Keuangan Negara Dalam Tindak Pidana Korupsi, First Printing, Yogyakarta, Dee-publish.

[10] Wiyono R., 2012, Pembahsan Undang - Undang Tindak Pidana Korupsi Second Edition, Third Printing, Jakarta, Sinar Grafika.

[11] Yusuf Muhammad, 2012, Merampas Aset Koruptor Solusi Pemberantasan Korupsi di Indonesia, Jakarta, Penerbit Buku Kompas.

\section{Thesis}

[1] Sulistyo Joko Hermawan, 2019, Penerapan Pidana Uang Pengganti Terhadap Pelaku Tindak Pidana Korupsi Suap dan Gratifikasi, Thesis, Universitas Islam Sultan Agung.

\section{Regulation}

[1] Act No. 8 of 1981 on the Criminal Procedure Code.

[2] Act No. 31 of 1999 as amended by Act No. 20 of 2001 concerning Amendments to Act No. 31 of 1999 concerning Eradication of Criminal Acts of Corruption.

[3] Indonesian Attorney General's Regulation Number: PER-013/A/JA/06/2014 dated 13 June 2014 concerning Asset Recovery. 